\title{
FDI Environment in China: A Critical Analysis
}

\author{
Manuel Fernandez ${ }^{1}$, Aysha Abdulla Ahmed Aljeed Alnuaimi ${ }^{1} \&$ Robinson Joseph ${ }^{1}$ \\ ${ }^{1}$ School of Business, Skyline University College, Sharjah, UAE \\ Correspondence: Manuel Fernandez, School of Business, Skyline University College, PO Box 1797, University City \\ of Sharjah, Sharjah, UAE. E-mail: qln_manuel@yahoo.com
}

Received: June 25, 2020

Accepted: July 28, 2020

Online Published: October 4, 2020

doi:10.5430/ijfr.v11n5p238

URL: https://doi.org/10.5430/ijfr.v11n5p238

\begin{abstract}
Investors prefer to invest in assets and places that offer attractive returns and are relatively less risky. China is one of the countries with the highest economic growth and is trying to attract investors from all corners of the world to invest and participate in the growth of China. The main objectives of this study are to evaluate the position of China as a destination for FDI, the factors that attract FDI into China, and the factors that hinder the flow of FDI into China. It also proposes to examine whether the attractiveness of China is increasing or is it on the decline and the rationale behind it. This study is based on secondary data, covers a period of five years, and analysis various determinants of FDI. The study reveals that China has the potential, political stability, and an organized financial system, but its market has started to shrink as the population growth is declining, the labor cost is increasing, labor market efficiency is decreasing, economic growth and infrastructure developments are decelerating, and corporate and individual tax rates are high.
\end{abstract}

Keywords: foreign direct investments, economic growth, infrastructure, market size

\section{Introduction}

In today's world, there is a great flow of investments between countries, investments flowing to destinations that are relatively more attractive than others. The investors be it individuals, corporates, or nations will always prefer to invest in assets that give attractive returns and are relatively less risky. Every asset, corporate, or country has different characteristics that attract different investors differently at different times (Fernandez \& Joseph, 2016). Foreign Direct Investment (FDI) is the investments made by a company in the investor country into a foreign, host country. It can be in the form of acquisition of an already existing host firm or establishment of new companies in the host country or entering into a joint venture with an existing host firm. The importance of FDI is growing because of the beneficial impact on both the host country's economy and a firm's performance and profitability.

The World Economy has seen a rapid rise in foreign direct investment for more than three and a half decades. Asia was the largest recipient of FDI in the World with a total of \$476 billion inflows in 2017 (Singh, 2019). The inflow of FDI gives developing countries access to capital that would otherwise be not available, as Transnational Corporations (TNCs) often have privileged access to capital from the international banking sector. Similarly, FDI provides the required foreign exchange and therefore helps to adjust some of the macroeconomic imbalances in developing countries. Foreign direct investments enable host countries to take advantage of their natural resources and develop their infrastructures, such as energy, water, communications, tourism, and other vital infrastructure projects and also contribute to training the local workforce, and development of industries through the various assets they offer, including the capital, technology, capabilities, management skills, and access to foreign markets (W. E. Tyner, 1998). Many countries in Asia, Africa, and in the Middle East are in the growth mode but the resources available for development with them are limited and inadequate, hence all these nations are competing against each other to make the investment climate better and project itself as the best FDI friendly destination.

China, officially known as the People's Republic of China is a country in East Asia. It is the world's most populous country, with a population of around 1.428 billion in 2018. Covering approximately 9,600,000 square kilometers, it is the world's fourth-largest country by area. Governed by the Communist Party of China, the state exercises jurisdiction over 22 provinces, five autonomous regions, four direct-controlled municipalities (Beijing, Tianjin, Shanghai, and Chongqing), and the special administrative regions of Hong Kong and Macau. Since the introduction of economic reforms in 1978, China's economy has been one of the world's fastest-growing with annual growth rates 
consistently above 6 percent. According to the World Bank, China's GDP grew from \$150 billion in 1978 to $\$ 14$ trillion by 2019. Since 2010, China has been the world's second-largest economy by nominal GDP, and since 2014, the largest economy in the world by PPP. China is also the world's largest exporter and second-largest importer of goods (Wikipedia, 2020). The peculiar nature of China is that the public sector of this nation accounts for a larger share of the national economy in comparison to the burgeoning private sector.

The World Investment Report (2019), reported that last year, global flows of foreign direct investment fell by 13\%, to $\$ 1.3$ trillion. This represents the lowest level since the global financial crisis and underlines the lack of growth in international investment this decade. Despite this global downward trend, China managed to attract a relatively substantial amount. Foreign direct investment, net inflows (BoP, current US\$) in China was reported at US $\$ 203,492,014,029$ in 2018, according to the World Bank collection of development indicators. Table 1 gives the data on the inflow of FDI into China during the period 2013 to 2018:

Table 1. Foreign direct investment in China: net inflows (US\$ in Million)

\begin{tabular}{lcccrrr}
\hline & 2013 & 2014 & 2015 & 2016 & 2017 & \multicolumn{1}{c}{2018} \\
\hline Net inflows & 290,928 & 268,097 & 242,389 & 174,750 & 166,084 & 203,492 \\
\hline Increase & & $-22,831$ & $-25,708$ & $-67,639$ & $-8,666$ & 37,408 \\
\hline Y-O-Y Growth & & $-7.85 \%$ & $-9.59 \%$ & $-27.91 \%$ & $-4.96 \%$ & $22.52 \%$ \\
\hline
\end{tabular}

Source: Compiled from World Bank database

The inflow of FDI during the period of the study had been decreasing in all years except in 2018. In 2018 the increase had been substantial at $22.52 \%$ over the previous year. In absolute terms, during the last five years, the inflow of FDI has decreased by US\$ 87,436 million, from US\$ 290,928 million in 2013 to US\$ 203,492 million in 2018, a decrease of approximately $30 \%$.

The main objectives of this study are to find out the status of China as a destination for FDI; the factors that attract FDI into China and how these can be sustained, and the factors that hinder the flow of FDI into China and how these can be reduced. The findings of the study would help the investors to arrive at a better decision on FDI into China, and similarly, help the regulators and other stakeholders to formulate appropriate policies and take necessary steps to enhance the FDI attractiveness of China. The rest of the paper is organized as follows. Section 2 provides brief literature on the determinants and advantages of FDI inflows. Section 3 explains the methodology. Section 4 presents the analysis and discussions. Finally, Section 5 presents some concluding remarks.

\section{Literature Review}

The flow of international capital has had the most important appearance in the emergence of globalization in a broader and more comprehensive way, and the most important characteristic of this is the intense competition between countries to attract the largest possible number and volume of foreign direct investments. Foreign direct investment is widely perceived as a powerful development engine for many receiving (host) countries. Virtually all countries are actively seeking to attract FDI, because of its expected favorable effect on income generation from capital inflows, advanced technology, management skills, and market know-how (Cho, 2003).

Numerous studies have been conducted in different parts of the world and majority of the studies have inspected the effects of determinants of FDI inflow and found that relevant determinants include the size and growth potential of the host market, economic stability, economic growth, infrastructure, human capital, interest rate, per capita income, exchange rate, wage rate, quality of institutions, etc. The presentation of the literature review is sequenced in such a manner that the literature relating to China is presented first, followed by market size, then political stability, followed by literature relating to all other factors.

Several works of literature studied the status of FDI in China from various aspects, such as the Zebregs (2002) study. This study reviews the Chinese experience in the field of foreign direct investment after the great importance that China had occupied in the second millennium of this century in this field of the economy, especially since foreign investment has enriched the Chinese economy and contributed to economic development significantly. The researchers studied the most important factors that contributed to making China occupy this position and become a destination for foreign direct investment, and they summarized the factors of success to the size of the Chinese market, labor licenses, advanced infrastructure, the presence of global economic experts and government facilities 
for foreign investment. The researchers also reviewed the returns of this investment in the country and found that foreign direct investment in China opened new doors for job opportunities and strongly supported the export sector. The study by Cai et al. (2004) has compared the foreign direct investment in China with selected developing and developed countries and found that China has great economic strength compared to other countries as it has become a destination for foreign direct investment and in conclusion in light of the massive industrial revolution that China is experiencing recently. The researchers believe that foreign direct investment is an important factor for global openness to the economies of other countries and the macroeconomy, and considering that foreign trade is the engine of the economy of any country, in the case of China, foreign direct investment is the engine of the post-industrial economic stage in the country.

Market size is presumed to have a positive relationship with FDI. Market-oriented FDI aims to set up firms to supply goods and services to the local market. The general implication is that host countries with larger market size, faster economic growth, and a higher degree of economic development will provide more and better opportunities for these firms to exploit their ownership advantages and therefore, will attract more market-oriented FDI (OECD, 2000). The study by Resmini (2000), looking into manufacturing FDI, finds that countries in Central and Eastern Europe with larger populations tend to attract more FDI. The studies by Kravis and Lipesey (1982), and Na and Lightfoot, (2006) revealed that FDI inflow has been largely attracted by the market size and market potential. Xaypanya et al. (2015) investigated the significant factors determining foreign direct investment in Cambodia, Laos, and Vietnam (ASEAN3) and Indonesia, Malaysia, the Philippines, Thailand, and Singapore (ASEAN5), and found that market size and infrastructure facility are significant factors to attract FDI. Dunning (1973) studied econometric models using a statistical analysis of surveys on the determinants of FDI and found that market forces such as market size, growth, and per capita income in the host country, and cost factors like labor cost and inflation as factors attracting FDI. Casi and Resmini (2010) inspected the determinants of FDI in the European Union region and found that the main determinants are the GDP growth rate, labor costs, and market potential. The study by Makki et al. (2004) on the US food processing industry found that market size, per-capita income, and openness significantly affected the US food processing firms' decisions to invest abroad. Thus one may presume that large host countries with a high growth rate and higher per capita income attract higher foreign direct investment due to larger potential demand.

Khachoo and Khan (2012) conducted a study to examine the determinants of FDI in 32 developing countries from 1982 to 2008 using an econometric model. Their empirical results showed that market size, total reserve, and infrastructure were positively related to FDI inflows.

Political stability and reliability determine the FDI inflows. TNCs prefer a stable government so that their investment is protected. Political instability may be in the form of the negative attitude of the government towards TNCs, non-allowance of fund transfer, currency convertibility, war, bureaucracy, and corruption. Political stability can also be measured by the number of changes of democratically elected governments (Gedam, 1996). The study by Root and Ahmed (1979), and Schneider and Frey (1985), looking at aggregate investment flows into developing economies found that political instability significantly affects FDI inflows.

Tax policies including corporate and personal tax rates influence inward FDI. Other things being equal a country with lower tax rates should stand a greater chance of attracting FDI projects than a country with higher rates (Chopra, 2003). According to Neumayer and De Soysa (2005), the availability of raw materials provides investors with an added advantage with regards to producing efficiently.

The study of Uwubanmwen and Ajao (2012) shows that trade openness, interest rate, government size, and GDP exerted a positive control on cross-border investments in Nigeria and a negative relationship was found between FDI and exchange rates. According to Milner (2013), the presence of a productive labor force is one of the determinants that influence the scope of FDI in a country.

A glance at the literature on the advantages of inflow of FDI shows that the foremost advantage of FDI is increased revenues that can be used for expanding growth opportunities in the investment destination. According to Almutawa and Maniruzzaman, (2014), investments by foreigners refer to additional revenue that supports various economic projects of a country. According to Muysken and Samia (2006), unemployment rates are reduced as a result of capital injections and job opportunities from foreign-based companies. FDI also increases the competitive advantage of a country by developing financial and business hubs that boost economic growth. Mina (2007) points out that FDI promotes the economic growth of a nation by stimulating various sectors of the economy such as manufacturing and tourism. 
The trend in FDI flows differs by region and country. Although FDI has innumerable effects on the economy of host countries and most countries are trying hard to attract FDI, the inflow of FDI continues to be uneven, with some countries getting the lion's share and others barely getting any.

\section{Methodology}

The main objectives of this study are to find out the status of China as a destination for FDI; the factors that attract FDI into China and how these can be sustained, and the factors that hinder the flow of FDI into China and how these can be reduced. The study is solely based on secondary data collected from local, regional, and international agencies like the Government of China, People's Bank of China, World Economic Forum, International Monetary Fund, Transparency International, World Bank Group, United Nations, and various publications of the statistical departments, governments, and the press. The study covers five years from 2014-2015 to 2018-2019. The collected data are tabulated and analyzed using appropriate analytical tools.

\section{Analysis and Discussions}

The Global Competitiveness Report 2019 published by the World Economic Forum assesses the competitiveness landscape of 141 economies, providing insight into the drivers of their productivity and prosperity. These 141 economies account for $99 \%$ of the world's GDP. The competitiveness ranking is based on indicators organized into 12 'pillars': Institutions; Infrastructure; ICT adoption; Macroeconomic stability; Health; Skills; Product market; Labor market; Financial system; Market size; Business dynamism; and Innovation capability. Each indicator or 'pillar' uses a scale from 0 to 100, to show how close an economy is to the ideal state or 'frontier' of competitiveness in that area (Global Competitiveness Report, 2019). The Report series remains the most comprehensive assessment of national competitiveness worldwide. Table 2 presents the year-wise ranking of China by the global competitiveness index for the year 2014 to 2019.

Table 2. Global competitiveness index: Ranking of China - 2014 to 2019

\begin{tabular}{lcccccc}
\hline Year & 2014 & 2015 & 2016 & 2017 & 2018 & 2019 \\
\hline Global Rank & 28 & 28 & 28 & 27 & 28 & 28
\end{tabular}

Source: Compiled from Global competitiveness reports from 2014 to 2019

The Global Competitiveness Reports have ranked China $28^{\text {th }}$ overall and it has remained at the same position throughout the study, with an exemption of a single position increase in 2017. Of course, it is ranked relatively high and is the best performer among the BRICS economies, but it is always a concern when one gets stuck at a particular point and struggles to improve from there, either because the steps taken by it is not sufficient or other economies are improving at a faster pace and may overtake China in the rankings and FDI attractiveness, soon. This calls for an analysis of various determinants of FDI beginning with the market size.

\subsection{Market Size}

Market size, growth in market size, and market efficiency are important determinants of FDI. The market size and the growth prospects of the market of the host country are important pull factors and are positively related to the level of FDI flows (Dunning, 1993 \& Chandalert, 2000). A large market size allows the attainment of economies of scale, and transaction costs are lower in countries with higher levels of economic development (Caves, 1971; Zhao \& Zhu, 2000).

China is the second-largest economy in the world. The population of China is more than 1.4 billion, and the GDP is $27,306.979$ billion. The market size can be measured by the population and the growth of the population of the country. Table 3 gives the population, the growth of population, population density, and land area of the top 10 countries with the highest population.

Table 3. Top ten countries with the highest population

\begin{tabular}{cccccccc}
\hline$\#$ & Country & 2000 & 2019 & 2050 & Growth Pop \% & $\begin{array}{c}\text { Density } \\
\left(\mathrm{P} / \mathrm{Km}^{2}\right)\end{array}$ & $\begin{array}{c}\text { Land Area } \\
\left(\mathrm{Km}^{2}\right)\end{array}$ \\
\hline 1 & China & $1,268,301,605$ & $1,420,062,022$ & $1,301,627,048$ & $11.90 \%$ & 153 & $9,388,211$ \\
\hline
\end{tabular}




\begin{tabular}{llrrrrrr}
\hline 2 & India & $1,006,300,297$ & $1,368,737,513$ & $1,656,553,632$ & $36.00 \%$ & 460 & $2,973,190$ \\
\hline 3 & United States & $282,162,411$ & $329,093,110$ & $398,328,349$ & $16.60 \%$ & 36 & $9,147,420$ \\
\hline 4 & Indonesia & $214,090,575$ & $269,536,482$ & $300,183,166$ & $25.90 \%$ & 149 & $1,811,570$ \\
\hline 5 & Brazil & $174,315,386$ & $212,392,717$ & $232,304,177$ & $21.80 \%$ & 25 & $8,358,140$ \\
\hline 6 & Pakistan & $152,429,036$ & $204,596,442$ & $290,847,790$ & $34.20 \%$ & 281 & 770,880 \\
\hline 7 & Nigeria & $123,945,463$ & $200,962,417$ & $391,296,754$ & $62.10 \%$ & 221 & 910,770 \\
\hline 8 & Bangladesh & $128,734,672$ & $168,065,920$ & $193,092,763$ & $30.50 \%$ & 1,253 & 130,170 \\
\hline 9 & Russia & $147,053,966$ & $143,895,551$ & $129,908,086$ & $-2.20 \%$ & 9 & $16,376,870$ \\
\hline 10 & Mexico & $99,775,434$ & $132,328,035$ & $150,567,503$ & $32.60 \%$ & 66 & $1,943,950$ \\
\hline
\end{tabular}

Source: Compiled from https://www.internetworldstats.com and https://www.worldometers.info

The size of the China market (based on population) has increased by $11.90 \%$ during the 10 years 2000 to 2019, but it is projected that the expected population will decrease to 1.3 billion by the year 2050. A declining population means that the domestic market is starting to shrink. Whereas its immediate powerful competitor India, is all set to have a stronger market with a population base of 1.65 billion by the year 2050, moreover in India the density of population is very high 460 per sq. $\mathrm{km}$, whereas it is only 153 per sq. $\mathrm{km}$ in China. India is the world's youngest major country, with $65 \%$ of the population under 35. Thus the future is not looking bright for China unless they come out with better strategies to counterbalance this. Table 4 gives the global ranking for China on market size for the period 2014 to 2019.

Table 4. Market size: Global competitiveness index ranking of China - 2014 to 2019

\begin{tabular}{ccccccc}
\hline Year & 2014 & 2015 & 2016 & 2017 & 2018 & 2019 \\
\hline Global Rank & 2 & 1 & 1 & 1 & 1 & 1 \\
\hline
\end{tabular}

Source: Compiled from Global competitiveness reports from 2014 to 2019

From 2015 onwards China is positioned at rank 1. It is appropriate to analyze the composition of the market. A market with a growing middle-class is quite attractive for any investor as, in the future, the market would be getting larger with a growing number of potential consumers with adequate purchasing power. Households making an annual income between $\$ 7,500$ and $\$ 60,000$ are classified as middle-class consumers, based on global averages. This trend explores how this middle-income class will have the potential to drive the global economy and will also emerge as a significant consumer base. The global middle-class is growing at a slow pace of $0.5 \%$ per year in developed regions, such as the United States, Japan, and Europe, whereas in developing countries, such as India and China, the y-o-y growth rate is nearly 6\%. Globally, the middle-class is expected to grow from 2 billion to nearly 5 billion within two decades and global spending is expected to grow by $\$ 29$ trillion. By 2030, more than $65 \%$ of the global middle-income class population will be residing in Asia. But the danger in this report is that, in the next 20 years, India is expected to add over one billion people to the global middle class. Thus, India could be the world's largest middle-class consumer market overtaking both China and the United States (Frost \& Sullivan, 2019). Thus, one may presume that China is losing its prominence and the future is bright for India, and naturally, investors will prefer to invest in India to reap the benefits of the predicted largest market base with the highest purchasing power, unless China strategies competitively.

\subsection{Economic Growth}

Over the past decade, growth in advanced economies has been very weak. Many emerging economies - including Argentina, Brazil, Russia, South Africa, and Turkey - are experiencing some slowdown or stagnation. In the least-developed economies, growth remains well below potential and is highly volatile. Productivity growth started slowing down well before the financial crisis of 2008. Between 2000 and 2007, total factor productivity (TFP) annual growth averaged just $1 \%$ in advanced economies and $2.8 \%$ in emerging and developing economies. TFP then plummeted during the crisis. Between 2011 and 2016, TFP grew by $0.3 \%$ in advanced economies and $1.3 \%$ in emerging and developing economies (Obstfeld and Duval, 2018). Corporates do not operate in a vacuum, they are highly influenced and attracted by the environmental factors and economic growth of the economy in which they do 
business. Corporates in high growth economies can envisage growing at a higher rate than those in the low growth countries as the environment highly influences the entity (Fernandez et al., 2020). For emerging economies like China, FDI is often referred to as the most effective way to transfer capital and technology from other economies especially the developed ones. Table 5 shows the annual percentage growth rate of GDP at market prices based on constant local currency, for China during the period 2014 to 2018.

Table 5. Economic growth of China - 2014 to 2018

\begin{tabular}{lllllll}
\hline Year & 2014 & 2015 & 2016 & 2017 & 2018 & Average \\
\hline Growth rate & $7.30 \%$ & $6.91 \%$ & $6.74 \%$ & $6.76 \%$ & $6.57 \%$ & $6.86 \%$ \\
\hline Global Rank & 16 & 18 & 18 & 22 & 20 & \\
\hline
\end{tabular}

Source: Compiled from TheGlobalEconomy.com, reports 2014 to 2018

The global average growth rate for 2018 was 3.31\%. In 2018, China had the 20th highest growth rate of $6.57 \%$. During the last five years, China was growing at an annual average rate of $6.86 \%$, which is one of the highest in the world. But from 2014 the growth rate has been slightly decreasing over the previous year, except in 2017, when there was a very marginal increase. Moreover, currently, global growth is slowing amid sluggish investment and weakening trade. Like many countries, China's economy is facing challenges, with consumption softening and investment slowing, which calls for immediate action from all stakeholders to bring back the economy into the track of high growth for a better future. The positive note for China is the 'Global Mega Trends to 2030' forecast report (Frost \& Sullivan, 2019), which forecasts that after 2020, economic growth in BRICS nations (China, one among them) will pick up the pace and the consolidated economy is expected to grow at a CAGR of $7.9 \%$ between 2018 and 2030; between 2021 and 2030, growth will be at its highest at 8.2\%.

\subsection{Infrastructure}

Infrastructure is a major determinant of FDI. Excellent infrastructure plays a major role in the productivity and profitability of Multinational Corporations (MNCs), and thus, their decision about FDI location. Table 6 gives the global ranking of China for the period 2014 to 2019 based on road connectivity, quality of road infrastructure, railroad density, the efficiency of train services, airport connectivity, the efficiency of air transport services, liner shipping connectivity, the efficiency of seaport services, utility infrastructure, electricity access, electricity supply quality, exposure to unsafe drinking water and reliability of water supply.

Table 6. Infrastructure: Global competitiveness index ranking of China

\begin{tabular}{lllllll}
\hline Year & 2014 & 2015 & 2016 & 2017 & 2018 & 2019 \\
\hline Global Rank & 46 & 39 & 42 & 46 & 29 & 36 \\
\hline
\end{tabular}

Source: Compiled from Global Competitiveness Reports 2014 to 2019

The infrastructure sector is a key driver for the Chinese economy. The sector is highly responsible for propelling China's overall development and the Government is continuously investing in infrastructure projects that would ensure the time-bound creation of a world-class infrastructure in the country. Despite all this, in 2019 the rank went down to 36, seven slots lower than the previous year, which shows that even though China's infrastructure is developing at a high rate, but other nations have grown at a higher rate and thus China got pushed to a lower rank. For getting a clearer picture let us glance into the Logistics Performance Index.

\subsubsection{Logistics Performance Index}

Logistics is the backbone of the trade, and good logistics can reduce trade costs and make countries compete globally. Getting logistics right, means improving infrastructure, skills, customs and regulations, policies, and governance in the right proportion. The Logistics Performance Index (LPI) is reported by the World Bank once in every two years, based on qualitative and quantitative data on six core performance components: (1) The efficiency of customs and border clearance, (2) The quality of trade and transport infrastructure, (3) The ease of arranging competitively priced shipments, (4) The competence and quality of logistics services, (5) The ability to track and trace consignments, (6) 
The frequency with which shipments reach consignees within scheduled or expected delivery times. Table 7 gives the ranking of China from 2014 to 2018.

Table 7. Logistics performance index: Ranking of China - 2014 to 2018

\begin{tabular}{llllllll}
\hline YPI & $\begin{array}{l}\text { Parameter-wise Global ranks } \\
\text { Gear } \\
\text { Rank }\end{array}$ & $\begin{array}{l}\text { Rusto } \\
\text { Rs }\end{array}$ & $\begin{array}{l}\text { Infrastructu } \\
\text { re }\end{array}$ & $\begin{array}{l}\text { International } \\
\text { shipments }\end{array}$ & $\begin{array}{l}\text { Logistics } \\
\text { competence }\end{array}$ & $\begin{array}{l}\text { Tracking \& } \\
\text { tracing }\end{array}$ & $\begin{array}{l}\text { Timelin } \\
\text { ess }\end{array}$ \\
\hline 2014 & 28 & 38 & 23 & 22 & 35 & 29 & 36 \\
\hline 2016 & 27 & 31 & 23 & 12 & 27 & 28 & 31 \\
\hline 2018 & 26 & 31 & 20 & 18 & 27 & 27 & 27 \\
\hline
\end{tabular}

Source: Compiled from Logistics Performance Index, 2014 - 2018

China's ranking in the World Bank's Logistics Performance Index (LPI) improved from 28 in 2014 to 27 in 2016, and 26 in 2018 globally. The position of China is appreciable and it is gradually and steadily improving. Moreover, China holds the top rank among the emerging markets according to the 2020 Agility Emerging Markets Logistics Index.

\subsection{Productive Labor Market}

The vibrant diversified labor force in China attracts foreign direct investments. When international investors look for an investment destination, considerations about the skilled nature of the labor force are a matter of priority that determines their scope of success in a country (Brakman \& Garretsen, 2008). Table 8 gives the data for the labor force which comprises people with ages 15 and older who supply labor for the production of goods and services during the period of study. It includes people who are currently employed and people who are unemployed but seeking work as well as first-time job-seekers.

Table 8. Labor force in China - 2014 to 2019

\begin{tabular}{lllllll}
\hline Year & 2014 & 2015 & 2016 & 2017 & 2018 & 2019 \\
\hline Labor Force (million) & 783.84 & 785.37 & 786.33 & 787.40 & 785.97 & 783.19 \\
\hline Global Rank & 1 & 1 & 1 & 1 & 1 & 1 \\
\hline
\end{tabular}

Source: Compiled from TheGlobalEconomy.com reports 2014 to 2019

Throughout the study, China had been retaining the top position. But one important trend to be noticed is that the number is gradually declining in China whereas the labor force in India is steadily growing and becoming larger year after year. Now let us look at the labor market efficiency, Table 9 gives the ranking for China on labor market efficiency during 2014 to 2019 based on cooperation in labor-employer relations, the flexibility of wage determination, hiring and firing practices, redundancy costs, active labor market policies, workers' rights, ease of hiring foreign labor, internal labor mobility, the effect of taxation on incentives to work, pay and productivity, reliance on professional management, and the ratio of women in the labor force.

Table 9. Labor market efficiency: Global competitiveness index ranking of China

\begin{tabular}{lllllll}
\hline Year & 2014 & 2015 & 2016 & 2017 & 2018 & 2019 \\
\hline Global Rank & 37 & 37 & 39 & 38 & 69 & 72 \\
\hline Source: Comp
\end{tabular}

Source: Compiled from Global competitiveness reports from 2014 to 2019

An efficient labor market, easy availability of skilled labor, the ready availability of training facilities, and the capacity to attract and retain the right talent from within the country and other parts of the globe are the most 
important factors that attract international investors. China was holding the rank 37 in 2014 and 2015, since then its labor market efficiency fell into a downward trend and it is holding a low rank of 72 in 2019. If this trend continues China will become an unattractive destination for FDI shortly.

\subsection{Political Risk}

TNCs usually assess political risk before investing in any country. There are many forms of political risks, but the extreme form is the possibility that the host country will take over a subsidiary. However, this form of political risk is an extreme case and not very common in today's global world. The more common forms of political risk include the negative attitude of the host government to TNCs, blockage of fund transfer, currency inconvertibility, war, bureaucracy, and corruption. Credendo Group provides business and economic data for 200 countries and has classified country risk under different indicators like political risk short term, political risk medium/long term, special transactions risk, transfer risk, expropriation risk, and political violence risk; under each of these indicators countries are classified into seven categories: from 1 (low risk) to 7 (high risk); among them, the last three are related to Direct Investments, and let us probe into that a little bite.

\subsubsection{Transfer Risk}

The currency inconvertibility and transfer restriction risk refer to the inability to convert and transfer out of the host country any funds related to the investment. The average value for China during the period of study is 2 for each year from 2014 to 2019. This indicates that currency inconvertibility and transfer restriction risk is low for China.

\subsubsection{Expropriation Risk}

The risk of expropriation encompasses all discriminatory measures taken by a host government which deprive the investor of its investment without any adequate compensation; and also includes events of the embargo, change of (legal) regime and denial of justice, and the probability of a negative change in attitude towards foreign investments. The average value for China during the period of study is 5 for each year from 2015 to 2019, an indication that expropriation risk is quite high in China.

\subsubsection{Political Violence Risk}

Political violence includes all violent act(s) undertaken with a political objective; and includes terrorism (political, religious, and ideological objectives) and political violence damage (damage to material assets as a result of political violence); business interruption as a result of political violence damage. To assess the political violence risk, the index looks at the actual levels of internal violence in and external conflict with a country, but also at the conflict potential that arises from (lingering) internal and external tensions, frustration and dissatisfaction. The value for China during the period of study is 3 , which indicates that the political violence risk is low for China. Table 10 gives the consolidated ranking for the period 2014 to 2019.

Table 10. Country risk: Credendo Group index ranking of China - 2014 to 2019

\begin{tabular}{lllllll}
\hline Year & 2014 & 2015 & 2016 & 2017 & 2018 & 2019 \\
\hline Transfer risk & 2 & 2 & 2 & 2 & 2 & 2 \\
\hline Expropriation risk & 4 & 5 & 5 & 5 & 5 & 5 \\
\hline Political violence risk & 3 & 3 & 3 & 3 & 3 & 3 \\
\hline
\end{tabular}

Source: Compiled from Credendo Group index reports 2014 to 2019

The international investors can be sure that they will get a warm welcome in China, their funds will not be blocked, enjoy easy convertibility, and fewer bureaucracy bottlenecks. Now let us go deeper into the level of corruption in China.

\subsubsection{Corruption}

Corruption distorts competition and investment and hinders free and fair trade. The study by Mauro (1995) found that corruption lowers investment and thereby economic growth. The study by Tanzi and Davoodi (1997) shows that corruption increases public investment while reducing its productivity. In regard to foreign direct investment, studies have shown that there exist economic consequences of corruption, the study by Wei and Smarzynska (1999) revealed that the foreign investor's choice of entry mode may be affected by the extent of corruption in a host country. 
Corruption makes dealing with government officials, for example, to obtain local licenses and permits, less transparent and costlier, particularly for foreign investors. In this case, having a local partner lowers the transaction cost, such as the cost of securing local permits. At the same time sharing ownership may lead to technology leakage. Both costs of local permits and losses from technology leakage are positively related to the extent of corruption in a host country.

When the corruption level is sufficiently high no investment will take place. China is one of the least corrupt countries in East Asian and offers a business-friendly environment, with an effective and efficient public administration. Transparency International (TI) has published the Corruption Perceptions Index since 1995, annually ranking countries by their perceived levels of corruption, as determined by expert assessments and opinion surveys. The CPI generally defines corruption as 'the misuse of public power for private benefit'. Table 11 displays the ranks assigned to China during the last six years.

Table 11. Corruption: Global ranking of China - 2014 to 2019

\begin{tabular}{lllllll}
\hline Year & 2014 & 2015 & 2016 & 2017 & 2018 & 2019 \\
\hline Global Rank & 100 & 83 & 79 & 77 & 87 & 80 \\
\hline
\end{tabular}

Source: Compiled from the Corruption Perceptions Index 2014 to 2019

The ranking by the Corruption Perceptions Index shows that the nation has to improve a lot in containing and controlling corruption, the data in the table shows that from 2014 to 2017 it was decreasing, but in 2018 suddenly, you observe an increase, and in 2019 it decreases to 80, this instability is not a pleasant sign for investors looking for friendly investor destinations.

\subsection{Interest Rates}

High interest rates tend to slow the growth of an economy and reduce the demand for the TNC's products and thus can negatively impact the flow of FDI. High loan interests translate into cost burden of a company and have been evidenced by the companies that decide to halt operations and move to other regions with low interest rates. From the perspective of an investor, low interest rates are better as compared to high rates because returns are high when the interest charges are low. Destinations with lower rates are bound to attract more investors than destinations with high interest rates. The lending rate is the bank rate that usually meets the short- and medium-term financing needs of the private sector. This rate is normally differentiated according to the creditworthiness of borrowers and the objectives of financing. Table 12 gives the lending interest rates in China for the period 2014 to 2018

Table 12. Lending interest rates in China - 2014 to 2018

\begin{tabular}{llllll}
\hline & 2014 & 2015 & 2016 & 2017 & 2018 \\
\hline Interest Rate & $5.60 \%$ & $4.35 \%$ & $4.35 \%$ & $4.35 \%$ & $4.35 \%$ \\
\hline Global Rank & 103 & 117 & 116 & 114 & 91 \\
\hline
\end{tabular}

Source: Compiled from TheGlobalEconomy.com reports 2014 to 2018

The global average lending interest rate for 2018 was $11.41 \%$. The lending rate in China is lower than the global average and it is stable from 2015 onwards, which is a very good sign as the lenders can avail loans at a lower cost, as the cost of capital impacts the corporate decisions and return on investment measuring parameters.

\subsubsection{Financial System}

The presence of financial institutions with sufficient liquidity and transparency to grant quick loans at competitive rates is an important determinant. The People's Bank of China is the central Bank of China and is responsible for carrying out monetary policy and regulation of financial institutions in mainland China. The People's Bank of China has the largest financial asset holdings of any central bank in the world. China's banking sector is the largest in the world by assets, with total assets of US40.1 Trillion in the first quarter of 2019. Table 13 lists the 10 largest banks in the world based on total assets. 
Table 13. Largest banks by total assets

\begin{tabular}{lllr}
\hline Rank & Bank name & Country & $\begin{array}{c}\text { Total } \\
\text { (US\$ Billion) }\end{array}$ \\
\hline 1 & Industrial and Commercial Bank of China & China & $4,027.44$ \\
\hline 2 & China Construction Bank & China & $3,376.52$ \\
\hline 3 & Agricultural Bank of China & China & $3,287.36$ \\
\hline 4 & Bank of China & China & $3,092.21$ \\
\hline 5 & Mitsubishi UFJ Financial Group & Japan & $3,069.20$ \\
\hline 6 & JPMorgan Chase & United States & $2,622.53$ \\
\hline 7 & HSBC Holdings PLC & United Kingdom & $2,558.12$ \\
\hline 8 & Bank of America & United States & $2,354.51$ \\
\hline 9 & BNP Paribas & France & $2,336.66$ \\
\hline 10 & Crédit Agricole & France & $2,123.61$ \\
\hline
\end{tabular}

Source: S\&P Global Market Intelligence report, 2019.

The table clearly shows that the largest four banks are Chinese banks, moreover out of the top 100 largest banks 18 are Chinese banks. Table 14 gives the ranking for the financial system of China 2014 to 2019 based on the availability of domestic credit to the private sector, financing of SMEs, venture capital availability, market capitalization, insurance premium, soundness of banks, non-performing loans as a percentage of loan portfolio value, credit gap and banks' regulatory capital ratio

Table 14. Financial system: Global competitiveness index ranking of China

\begin{tabular}{lllllll}
\hline Year & 2014 & 2015 & 2016 & 2017 & 2018 & 2019 \\
\hline Global Rank & 54 & 54 & 56 & 48 & 30 & 29 \\
\hline
\end{tabular}

Source: Compiled from Global competitiveness reports from 2014 to 2019

China had been improving steadily during the period of study, progressing from a low of 54 in 2014 to rank 29 in 2019.

\subsection{Tax Rates and Clarity of Taxation Policies}

Lower tax will give corporates and individuals more after-tax income that could enhance the wealth of the corporates and individuals could use for buying more goods and services, or for saving. Investors prefer lower-tax locations to locate or relocate their businesses.

\subsubsection{Corporate Tax}

Table 15 gives the corporate tax rates for China, India, and a few selected countries from Asia, and the averages.

Table 15. Corporate Tax Rates (in \%) for select countries - 2014 to 2019

\begin{tabular}{lcccccc}
\hline & 2014 & 2015 & 2016 & 2017 & 2018 & 2019 \\
\hline Afghanistan & 20 & 20 & 20 & 20 & 20 & 20 \\
\hline Bangladesh & 27.5 & 25 & 25 & 25 & 25 & 25 \\
\hline India & 33.99 & 34.61 & 34.61 & 34.61 & 35 & 30 \\
\hline Pakistan & 34 & 33 & 32 & 31 & 30 & 30 \\
\hline Sri Lanka & 28 & 28 & 15 & 28 & 28 & 28 \\
\hline China & 25 & 25 & 25 & 25 & 25 & 25 \\
\hline Asia average & 22 & 21.98 & 21.41 & 21.08 & 21.21 & 21.09 \\
\hline Global average & 23.88 & 23.77 & 23.62 & 24.06 & 24.02 & 23.79 \\
\hline Soure: Con
\end{tabular}

Source: Compiled from KPMG data 
The corporate tax rates in China is quite high and is higher than the Asian and global average. The policymakers will have to reduce the tax rates to make China friendlier to the corporates operating in China and to attract MNCs from around the globe to invest in China.

\subsubsection{Income Tax}

Table 16 gives the individual income tax rates for China, India, and a few selected countries from Asia, and the averages.

Table 16. Income tax rates (in \%) for select countries - 2014 to 2019

\begin{tabular}{lcccccc}
\hline & 2014 & 2015 & 2016 & 2017 & 2018 & 2019 \\
\hline Afghanistan & 20 & 20 & 20 & 20 & 20 & 20 \\
\hline Bangladesh & 30 & 30 & 30 & 30 & 30 & 30 \\
\hline India & 33.99 & 33.99 & 35.54 & 35.54 & 35.88 & 35.88 \\
\hline Pakistan & 20 & 20 & 20 & 20 & 20 & 20 \\
\hline Sri Lanka & 24 & 24 & 15 & 16 & 24 & 24 \\
\hline China & 45 & 45 & 45 & 45 & 45 & 45 \\
\hline Asia average & 27.2 & 27.09 & 27.35 & 27.65 & 27.67 & 27.99 \\
\hline Global average & 31.08 & 30.8 & 30.97 & 31.41 & 31.39 & 31.23 \\
\hline
\end{tabular}

Source: Compiled from KPMG data

The individual income tax rates are very high in China, all the years during the period of study the individual income tax rate in China is higher than all other Asian countries, it is also higher than the Asian and the global average. The policymakers will have to give a proper thought as to how to reduce tax without heavily impacting the revenue of the nation. Lower income tax reduces the cost of running a business because at the time of salary negotiations the prospective employee looks at the after-tax annual pay package offered. The country will have to carry out reforms in the taxation policy to attract the highly talented and skilled workforce needed for the domestic and MNCs operating in the country.

\subsection{Availability / Easiness to Import of Raw Materials}

Availability of raw materials means that international investors can do business in the country without having concerns about the supply of production materials. In China, there is a wide range of raw materials that can be used for manufacturing processes and has motivated many investors abroad to invest in the country. The import-export policy is quite friendly and liberal, which permits manufacturers to import those raw materials that are not readily available in the country. But, the government will have to still improve the polices to attract more FDI into the country

\subsection{Technology Adoption and Innovation}

Technology is an important consideration for foreign investors because it determines the scope of operational efficiency. From an investment perspective, the lack of efficient technology systems implies that operations would be slow and costly, and, thus, there will be a need for choosing destinations with a higher level of technology. Table 17 gives the ranking for China on ICT adoption from 2014 to 2019 based on mobile-cellular telephone subscriptions, mobile-broadband subscriptions, fixed broadband internet subscriptions, fiber internet subscriptions, and internet users.

Table 17. ICT adoption: Global competitiveness index ranking of China

\begin{tabular}{lcccccc}
\hline Year & 2014 & 2015 & 2016 & 2017 & 2018 & 2019 \\
\hline Global Rank & 83 & 74 & 74 & 73 & 26 & 18 \\
\hline
\end{tabular}

Source: Compiled from Global competitiveness reports from 2014 to 2019 
In ICT adoption China has improved dramatically from rank 83 in 2014 to rank 18 in 2019. Table 18 gives the ranking for China on innovation friendliness from 2014 to 2019 based on diversity of the workforce, state of cluster development, international co-invention, multi-stakeholder collaboration, scientific publications, patent applications, R\&D expenditures, prominence of research institutions, buyer sophistication and applications made for trademark.

Table 18. Innovation capacity: Global competitiveness index ranking of China

\begin{tabular}{lcccccc}
\hline Year & 2014 & 2015 & 2016 & 2017 & 2018 & 2019 \\
\hline Global Rank & 32 & 31 & 30 & 28 & 24 & 24 \\
\hline Source: Comple
\end{tabular}

Source: Compiled from Global competitiveness reports from 2014 to 2019

In innovation friendliness China is showing plenty of improvement, its rank has improved from 32 in 2014 to 24 in 2019. Now let us also look at the ranking by Global Innovation Index (GII) co-published by Cornell University, INSEAD, and the World Intellectual Property Organization (WIPO, an agency of the United Nations). The Index is a ranking of the innovation capabilities and results of world economies. It measures innovation based on criteria that include institutions, human capital and research, infrastructure, credit, investment, linkages; the creation, absorption and, diffusion of knowledge; and creative outputs. Table 19 gives the ranking of China in the Global Innovation Index from 2014 to 2019.

Table 19. Global innovation index: China's ranking - 2014 to 2019

\begin{tabular}{lcccccc}
\hline Year & 2014 & 2015 & 2016 & 2017 & 2018 & 2019 \\
\hline GII & 29 & 29 & 25 & 22 & 17 & 14 \\
\hline Innovation Inputs & 45 & 41 & 29 & 31 & 27 & 26 \\
\hline Innovation Outputs & 16 & 21 & 15 & 11 & 10 & 5 \\
\hline
\end{tabular}

Source: Compiled from the Global Innovation Index 2014 to 2019

Over the last five years, China has continued to improve its ranking in innovation outputs, reaching the fifth position this year, up from 16 in 2014. Similarly, innovation inputs also improved to ranking 26 up from 45 in 2014. The above data show that China is doing quite well and has in place policies that are friendly to technology adoption and innovations.

\subsection{Ease of Doing Business}

The World Bank Group's Doing Business report tracks the regulatory and bureaucratic systems of nations by conducting detailed annual surveys with the goal to provide an objective basis for understanding and improving the regulatory environment for businesses around the world. Doing Business report captures several important dimensions of the regulatory environment as it applies to local firms. It provides quantitative indicators on regulation for starting a business, dealing with construction permits, getting electricity, registering property, getting credit, protecting minority investors, paying taxes, trading across borders, enforcing contracts, and resolving insolvency. These reports provide data on the ease of doing business, rank each location, and recommend reforms to improve performance in each of the indicator areas

Doing Business Report ranks economies based on their ease of doing business. A high ease of doing business ranking means the regulatory environment is more conducive to the starting and operation of a local firm. The rankings are determined by sorting the aggregate distance to frontier scores on 10 topics, each consisting of several indicators, giving equal weight to each topic. Table 20 gives the ranking for China from 2015 to 2020.

Table 20. Ease of doing business: China's ranking - 2015 - 2020

\begin{tabular}{lcccccc}
\hline Year & 2015 & 2016 & 2017 & 2018 & 2019 & 2020 \\
\hline Global Rank & 90 & 84 & 78 & 78 & 46 & 31 \\
\hline
\end{tabular}

Source: Compiled from the Doing Business Report 2015 to 2020 
Doing Business data for the past six years shows that the position of China is improving gradually and steadily, it has improved a lot from position 90 in 2015 to position 31 in 2020. China was ranked 31 out of 190 countries in the World Bank's 2020 Doing Business report, a major improvement from 2019 when it was ranked 46 out of 190. China was one of the top 10 economies to improve the most between the 2019 and the 2020 reports. This progress reflects the improvement in a wide array of subcomponents ranging from procedures for starting a business to measures to improve electricity access and getting construction permits. China demonstrated reform agendas that aim to improve the business regulatory environment in the country over the course of several years. The reforms mainly focus on increasing the efficiency of business processes, such as tax cuts, trade with tariff cuts, streamline customs clearance, and reduced barriers to foreign investors by establishing an online filing system to regulate FDI

\subsection{Impact of Current Economic Scenario and Coronavirus Covid-19}

We are facing a crisis the world has never seen the likes of in modern history, a crisis marked by uncertainty. The planet-wide pandemic has caused untold misery to humankind. People everywhere have been robbed of those they love, parents, grandparents, spouses, children and friends.

The high-temperature argument over blame for the coronavirus is rapidly pushing the United States and China into a potentially dangerous Cold War. Dozens of American virus patients and some US businesses are taking legal steps. They are attempting to sue China over the spread of the virus, which has killed more than 200,000 people in the US. A number of lawsuits have been filed in the U.S. against China claiming authorities there did not do enough to corral the virus initially, tried to hide what was happening in Wuhan and sought to conceal their actions and what they knew.

Even before the outbreak of the coronavirus pandemic, many companies had their plans to relocate as the costs in China were already trending up for some time, and because of the trade and economic frictions between China and the United States of America. A study by Japanese investment bank Nomura found that 56 companies relocated production from China between April 2018 and August 2019. Out of which, three companies went to India, two to Indonesia, eight to Thailand, eleven to Taiwan, and twenty-six to Vietnam.

Re-locating manufacturing facilities is not a small matter. There are high initial set-up costs, then the appropriateness of the infrastructure, communications and connectivity, availability of good and cost-effective warehousing, transportation and other logistical support, availability of the right skilled manpower and their willingness and ability to undergo specific training required for the proposed production process. This is where China loses and other emerging economies stand a chance if the leaders of those nations have taken initiatives to attract these companies looking out for an appropriate place to relocate.

India has a great opportunity to emerge as a global manufacturing hub as foreign companies reassess their production bases in China, especially, when the pandemic and attempts to contain it have sharply cut the world's appetite for China's goods and services. Around 1,000 foreign firms are presently engaged in conversations with Indian authorities, and at least 300 are actively pursuing production plans in India in sectors such as smartphones, electronics, medical devices, textiles, and synthetic fabric. Companies like Samsung and Apple are already making some of their mobile phones in India. Apple which has already been manufacturing iPhone components and older models in India expects to start building the newer iPhone XS and SR in India this year. The Samsung factory in Noida is one of its biggest in the world.

Land and labor laws had been the biggest impediments for companies looking to invest in India. The coronavirus crisis has opened up a window for India with a chance to finally push through long-stalled reforms on land, labor, and taxes that have hindered investment for years. At present, investors keen on setting up a factory in India need to acquire land on their own. The process, in some cases, delays the project as it involves negotiating with small plot owners to part with their holding. To overcome this, India is developing a land pool nearly double the size of Luxembourg to lure businesses moving out of China. An area of 461,589 hectares has been identified across the country for the purpose. India is bringing in drastic restructuring of the labor laws. Several states led by Uttar Pradesh, Madhya Pradesh, and Gujarat have already enacted drastic changes in labor laws. India certainly has an edge to be an alternative manufacturing site of choice, as the cost of labor is low - the entry-level salaries for workers in India start between US\$157 and US\$196, while in China the salaries are about three times higher. The labor force in India is steadily growing and becoming larger year after year, India is the world's youngest major country, with $65 \%$ of the population below the age of 35 . India also offers lower operating costs, competitive infrastructure, special economic zones (SEZs) that offer duty-free exports among other benefits, incentives to boost domestic manufacturing, and business-friendly policies. Plus, while China is engulfed in a trade war with the US, India has a comparatively good relationship with the US with both countries currently engaged in bilateral trade talks. Moreover, India has announced a number of reforms, which include: reduction of the effective corporate tax rate for new 
manufacturing companies to $17 \%$, and is in the process of announcing tax holidays extending up to 10 years based on the quantum of initial investments. Thus for investors seeking alternative destinations to diversify their manufacturing and supply chains, India has emerged as an alternative hub for global manufacturing, with low labor costs, incentives and regulatory relaxations for manufacturing, and a reduced corporate tax rate, investor-friendly land and labor laws.

\section{Conclusion}

It is highly appreciable for a country that emerged from abject poverty and isolation more than 40 years ago, to become one of the fastest-growing economies of the world. China is quite highly ranked at 28 in the Global Competitiveness Reports, but it has remained at the same rank during the period of study, a sign of stagnation or that China is losing its attractiveness to global investors, who are attracted by the future cash flows and returns and not historical returns and diminishing attractiveness.

China's strengths include the size of its market and macroeconomic stability. The size of the market has increased by $11.90 \%$ during the 10 years 2000 to 2019, but it is projected that the expected population will decrease to 1.3 billion by the year 2050. A declining population means that the domestic market is starting to shrink, and in the near future, China would be losing one of their supreme strengths - the large market size. While its close competitor India, is all set to have a stronger market with a population base of 1.65 billion by the year 2050, thus from this perspective the future is not promising for China.

With a wealth of employees and potential partners' eager to learn and evolve, China is a base for low-cost production, which makes it an attractive market for investors; but the labor cost in China had been increasing during the last few years and currently it is almost three times that of India, which again makes India preferable to China. Moreover, in China, the functioning of the labor market is severely undermined by insufficient workers' rights protection, rigidities in wage determination and redundancy, conflictual industrial relations, low participation of women, high tax on labor, and lack of internal mobility. Relatively, India has a younger population than China. India is the world's youngest major country, with $65 \%$ of the population under 35 . Moreover, India is bringing in drastic restructuring of its labor laws with the sole intent of attracting more global investors.

The labor market efficiency is decreasing, China was holding rank 37 in 2014 and 2015, since then its labor market efficiency fell into a downward trend and it is holding a low rank of 72 in 2019. If this trend continues China will become an unattractive destination for FDI in the near future.

The economic growth rate of China had been declining over the past few years. Infrastructure is also well developed, but the Global Competitiveness reports show that the rank decreased from 29 in 2018 to 36 in 2019, which shows that the infrastructure developments are decelerating in China. But China has been rapidly increasing its ICT adoption and innovation capability.

China was one of the top 10 economies to improve the most between the 2019 and 2020 in the Ease of Doing Business reports, which reflects improvements in a wide array of subcomponents like procedures for starting a business, measures to improve electricity access, procedures to get construction permits, improved business regulatory environment, tax cuts, and online filing system. But, the factors hindering investment are China's lack of transparency, legal uncertainty, bureaucratic and administrative complexities, ageing population, production overcapacity in several sectors, underdeveloped middle management and low rate of qualified work, cultural differences, low level of protection of intellectual property rights, corruption or protectionist measures which favor local businesses. The corporate and individual tax rates in China are very high and is higher than the Asian and global average.

Trade and economic frictions between China and the US, and the rising cost in China, has already prompted MNCs to relocate or think to relocate production from China. In addition to this, the outbreak of the coronavirus pandemic and attempts to contain it have sharply cut the world's appetite for China's goods and services and is compelling companies to actively look for geographical diversifications of their manufacturing and production facilities, in order to reduce the impact of similar havocs in the global supply chain in future. All this collectively reduces the attractiveness of China as an FDI destination of the future.

Limitations of this study are that the impact of current Novel Coronavirus COVID-19 is not fully factored into the study, as it is still an ongoing pandemic, hence the investors are requested to factor in that while making the investment decisions.

\section{References}

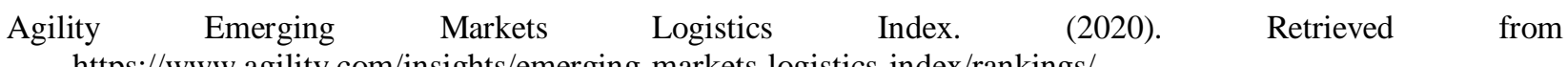
https://www.agility.com/insights/emerging-markets-logistics-index/rankings/ 
Almutawa, A. M., \& Maniruzzaman, A. F. M. (2014). The UAE's pilgrimage to international arbitration stardom: a critical appraisal of Dubai as a center of dispute resolution aspiring to be a Middle East business hub. The journal of World Investment \& Trade, 15(1-2), 193-244.

Brakman, S., \& Garretsen, H. (Eds.). (2008). Foreign direct investment and the multinational enterprise. MIT Press.

Business and economic data for 200 countries. Retrieved from https://www.theglobaleconomy.com/download-data.php

Cai, F., Cheng, H., Xu, L., \& Leung, C. K. (2004). Economic Growth and FDI in China. International Business \& Economics Research Journal (IBER), 3(5). https://doi.org/10.19030/iber.v3i5.3687

Casi, L., \& Resmini, L. (2010). Evidence on the determinants of foreign direct investment: the case of EU regions. Eastern Journal of European Studies, 1(2), 93-118.

Caves, R. E. (1971). International corporations: The industrial economics of foreign investment. Economica, 38(149), $1-27$.

Chandprapalert, A. (2000). The determinants of US direct investment in Thailand: A survey on managerial perspectives. Multinational Business Review, 8(2), 82-88.

Cho, J. W. (2003). Foreign direct investment: determinants, trends in flows and promotion policies. Investment Promotion and Enterprise Development Bulletin for Asia and the Pacific, 1, 99-112.

Chopra, C. (2003). Foreign investment in India. Deep \& Deep Publications.

Credendo Group index reports. Retrieved from https://www.credendo.com/country-risk

Doing Business Global Ranking. (2020). World Bank Group. Retrieved from: http://www.doingbusiness.org/rankings

Dunning, J. H. (1973). The determinants of international production. Oxford economic papers, 25(3), 289-336.

Fernandez, M., \& Joseph, R. (2016). UAE the Attractive FDI Destination in the Middle East. International Research Journal of Finance and Economics, (153).

Fernandez, M., Shubaisi, A. M., \& Joseph, R. (2020). Examination of potentialities of Vietnam as FDI destination. Journal of Economics and Business, 3(3), 980-994.

Frost \& Sullivan. (2019, Sep.). Global Mega Trends to 2030 - Futurecasting Key Themes that will Shape Our Future Lives. Retrieved from https://store.frost.com/global-mega-trends-to-2030.html

Gedam, R. (1996). Determinants of FDI and India's experience (2nd ed.) Deep and Deep Publication, New Delhi.

Global Competitiveness Report. (2019). Retrieved from https://www.weforum.org/reports/how-to-end-a-decade-of-lost-productivity-growth

Global Innovation Index. (2019). Retrieved from https://www.globalinnovationindex.org/content/page/data-analysis/ Khachoo, A. Q., \& Khan, M. I. (2012). Determinants of FDI inflows to developing countries: a panel data analysis.

KPMG data. Retrieved from https://home.kpmg/xx/en/home/services/tax/tax-tools-and-resources/tax-rates-online/corporate-tax-rates-table.ht $\mathrm{ml}$

KPMG data. Retrieved from https://home.kpmg/xx/en/home/services/tax/tax-tools-and-resources/tax-rates-online/individual-income-tax-rate s-table.html

Kravis, I., \& Lipesey, R. (1982). The location of overseas production and production for export by US Multinational firms. Journal of International Economics, 12(3), 201-23.

Logistics Performance Index. (2018). Retrieved from http://lpi.worldbank.org/international/global

Makki, S. S., Somwaru, A., \& Bolling, C. (2004). Determinants of foreign direct investment in the food-processing industry: a comparative analysis of developed and developing economies. Journal of Food Distribution Research, 35(3), 60-7.

Mauro, P. (1995). Corruption and growth. The Quarterly Journal of Economics, 110(3), 681-712.

Milner, H. V. (2013). The regime for international investment: foreign direct investment, bilateral investment treaties, and trade agreements. 
Mina, W. (2007). The location determinants of FDI in the GCC countries. Journal of Multinational Financial Management, 17(4), 336-348.

Muysken, J., \& Nour, S. (2006). Deficiencies in education and poor prospects for economic growth in the Gulf countries: The case of the UAE. The Journal of Development Studies, 42(6), 957-980.

Na, L., \& Lightfoot, W. S. (2006). Determinants of foreign direct investment at the regional level in China. Journal of Technology Management in China, 1(3), 262-78.

Neumayer, E., \& De Soysa, I. (2005). Trade Openness, Foreign Direct Investment and Child Labor. World development, 33(1), 43-63.

Obstfeld, M., \& Romain, D. (2018). Tight monetary policy is not the answer to weak productivity growth. Retrieved from https://voxeu.org/article/tight-monetary-policy-not-answer-weak-productivity-growth

OECD. (2000). Main determinants of FDI and its impact of foreign direct investment on China's economy. Working papers on international investment no. 4, prepared for OECD cooperation programme.

Resmini, L. (2000). The determinants of foreign direct investment in the CEECs: New evidence from sectoral patterns. Economics of Transition, 8(3), 665-689.

Root, F. R., \& Ahmed, A. A. (1979). Empirical determinants of manufacturing direct foreign investment in developing countries. Economic Development and Cultural Change, 27(4), 751-767.

Schneider, F., \& Frey, B. S. (1985). Economic and political determinants of foreign direct investment. World Development, 13(2), 161-175.

Singh, S. (2019). Foreign Direct Investment (FDI) Inflows in India a Review. Journal of General Management Research, 6(1), 41-53.

Tanzi V. \& Davoodi H. (1997). Corruption, public investment and growth. IMF Working Paper, WP/97/139.

Transparency International, the Corruption Perceptions Index. Retrieved from http://www.transparency.org

Uwubanmwen, A. E., \& Ajao, M. G. (2012). The Determinants of foreign direct investment in Nigeria. International Journal of Business and Management, 7(24), 67-77.

Wei, S. J., \& Smarzynska, B. (1999). Corruption and the composition of foreign direct investment: Firm-level evidence. The World Bank.

Wikipedia. (2020). Retrieved from https://en.wikipedia.org/wiki/China

World Bank database. Retrieved from https://data.worldbank.org

World Investment Report. (2019). United Nations Conference on Trade and Development. Retrieved from https://unctad.org/en/pages/PublicationWebflyer.aspx?publicationid=2460

Worldometer, density and land area. Retrieved from https://www.worldometers.info/world-population/population-by-country/

Xaypanya, P., Rangkakulnuwat, P., \& Paweenawat, S. W. (2015). The determinants of foreign direct investment in ASEAN. International Journal of Social Economics, 42(3), 239-250.

Zebregs, M. H., \& Tseng, M. W. (2002). Foreign direct investment in China: some lessons for other countries (No. 2-3). International Monetary Fund.

Zhao, H., \& Zhu, G. (2000). Location factors and country-of-origin differences: An empirical analysis of FDI in China. Multinational Business Review, 8(1), 60-73.

\section{Copyrights}

Copyright for this article is retained by the author(s), with first publication rights granted to the journal.

This is an open-access article distributed under the terms and conditions of the Creative Commons Attribution license (http://creativecommons.org/licenses/by/4.0/). 